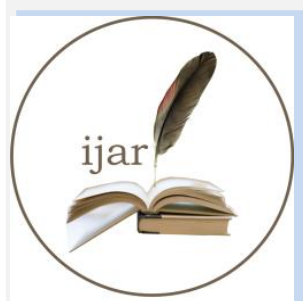

ISSN NO. 2320-5407 \section{INTERNATIONAL JOURNAL OF ADVANCED RESEARCH (IJAR)}

Journal Homepage: - www.journalijar.com

Article DOI: $10.21474 / \mathrm{IJAR01/1422}$

DOI URL: http://dx.doi.org/10.21474/IJAR01/1422
INTERNATIONAL JOURNAL OF ADVANCED RESEARCH (JJAR)

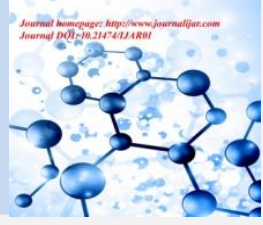

RESEARCH ARTICLE

\title{
DIALOGISM AS A PATHWAY TO CREATIVITY IN TEACHER EDUCATION FOR ACHIEVING SUSTAINABLE DEVELOPMENT.
}

\author{
Dr. JihanZayed. \\ Humanities and Administration College, Qassim Private Colleges, Buraidah, KSA.
}

\section{Manuscript Info}

Manuscript History

Received: 12 June 2016

Final Accepted: 19 July 2016

Published: August 2016

Key words:-

Dialogism, Bakhtin, creativity, sustainable development .

\begin{abstract}
This paper aims to introduce and investigate creativity as a key element of achievingsustainable development. Conceptually, it adopts a postnormal perspective of creativity and focuses on Mikhail Bakhtin's theory of dialogism as a pathway to it. Empirically, it is aparticipative qualitative research introducing the notion of creativity to the students enrolled at the English department, Humanities and Administration College, Qassim Private Colleges to help those students - as prospective teachers - to be creative teachers designing teaching aids related to the contents of their courses. This study was conducted upon 160 female studentsduring the first term of the academic year 20152016. At the end of the term, those students were introduced to a competition entitled "The Most Creative Project". Intending to investigate how those students conceived of and worked for creativity, they underwent a survey after the Project Fair. They reported that their participation in that experience enabled them to exchange ideas. They concluded that all of them excelled in introducing their creative projects.
\end{abstract}

Copy Right, IJAR, 2016,. All rights reserved.

\section{Introduction:-}

Dialogism as a Pathway to Creativity in Teacher Education for Achieving Sustainable Development Nowadays, changes occur at an accelerating speed. Some scholars argue that the world goes through "post- normal times": turbulent timesloaded with uncertainty, and high levels of complexity. In such times, conventional routines and systems nolonger seem to work. Sustainable development is a concern of several UN agencies that appreciate a need to rethink dominant short-term approaches and limited understanding of life.This paradigmatic "whole system redesign" perspective requires acreative wayof thinking and acting, bearing in mind that our world is one of continuous change andever-present uncertainty. One of the original descriptions ofsustainable development is credited to the World Commission onEnvironment and Developmentknown as Brundtland Commission(1987, p. 43): "Sustainabledevelopment is development that meets the needs of the present without compromisingthe ability of future generations to meet their own needs" (Tilbury\&Mulà, 2009; Wals\&Schwarzin, 2012).

Education has long been identified as key to translating the ideals ofsustainable development into practice through enhancing people's skills and capacities. UNESCO is the United Nations' Lead Agency for the UN Decade on Education for Sustainable Development (ESD, 2005-2014) which called for: 
... a world in which the values inherent in sustainable development are integrated into all aspects of learning in order to encourage changes in behaviour that allow for a more sustainable, economically viable and just society for all, a world where everyone has the opportunity to benefit from education and learn the values, behaviour and lifestyles required for a sustainable future and for positive societal transformation (as quoted in a Foreword to Tilbury\&Mulà, 2009, p. 4).

What legitimates this approach to education is context. Numerous high level reports and booksconsistently remind us that, in the words of Al Gore's latest book The Future (2012) there is"a clear consensus that the future now emerging will be extremely different from anything wehave ever known in the past"p.xv. Consequently,

Therefore, ESD promises to make theworld more livable for this and future generations.It allows to improve quality of life today in all economic,environmental, and social dimensions, without impairing the ability of future generations to enjoy quality of lifeand opportunity at least as good as ours. Being more than a knowledge base,ESD also addresses learning skills, perspectives, and values that guide and motivate peopleto seek sustainable livelihoods, participate in a democratic society, and continue learning after they leaveschoolto live sustainable lives(McKeown, 2002; Evans\& Jones, 2008).The proposal for a global action programme to follow the decade for ESD (2014-2020) focuses on "innovative, participatory teaching and learning methods that empower and motivate learners to take action for sustainable development" (UNESCO, 2013, p. 2).

As key change agents, teachers have an important rolein efforts to move towards a more sustainable life. Teachers touch the lives of millions of learners in specific ways. Teachers help shape learners' world views, economic potentials and attitudes towards others in the community. Teachers also help form an individual's participation in community decision making and interaction with the environment. Institutions of teacher education fulfill vital roles in the development of teachers who can become skilled advocates for, and practitioners in, creativity in schools; they have the potential to bring changes within educational systems that will shape the knowledge and skills of future generations. Learning for sustainability recognises that teaching is not value-neutral - the learning experience is shaped by the values of teachers. Teachers should promote through their pedagogy and curriculum the values which will be required in learners to create sustainable futures (Evans \& Jones, 2008; The Higher Education Academy, 2014).

\section{Review of Literature:-}

Creativity is now generally agreed by educational policy makers to be an important skill for the knowledge age and governments across the world are seeking to promote the teaching of creativity. A UK government commission defined creativity as: 'Imaginative activity fashioned so as to produce outcomes that are original and of value' (NACCCE, 1999: 29) neatly combining in one sentence the two sides of creativity which often seem incompatible, "imaginative activity" or just "playing around" on the one side and products with social "value" on the other. Governments who seek to promote creativity are almost certainly more interested in the production of socially valued products than they are in promoting more "imaginative play" for its own sake in classrooms.

O'brien (2012) defines creativity as "a sustainable, replicableintellectual practice that transcends subject areas and informs innovation and knowledge growth" pp. 316-317. This view makes creativity an "ordinary"process that is generally accessible and teachable, andcertainly well within the reach of the motivated teacher.For her, there is a difference between "teachingcreatively" and "teaching for creativity."The former involves fostering students" interests and motivation in learning.In contrast,the latter relatesto developing students' own creative thinking andbehavior.Teaching that develops creativity entails the development ofthe common capabilities and sensibilities of creativity (curiosity, creative processesand practices, etc.), the encouragement of students to believe in their creativeidentities, as well as the development of a sense of agency and self-determination inthe learning process.

Trausan-Matu(2010)defines creativity as "a mental activity in the minds of particular persons with the role of the community which validates the novelty" p. 82. Creative people are characterized by autonomy, independence andnonconformism, and imagination. They exhibit curiosity, search of problems, high intelligence,insight, motivation and divergent thinking. Creative people are critical: they do not stop to what is given obviously. They are creative and make a habit of thinking in a more open andflexible and anticipative way.

Students' creativity can be increased by extended participation in creative projects, sharing of knowledge and motivation of all of them.Given the traditional lethargy in the educational system, Chappell andCraft (2011)confirm 
that active students' involvement in dialogueis requiredto guide their shared learning of creativity beyond what colleges typically engage in.According toBakhtin's(1984), dialogue is directly linked to creativity as information is not transferred, but, rather, produced; any literal, single-voiced word is naive and unsuitablefor authentic creativity. Trausan-Matu(2010) confirms thatcarnivalesque at Bakhtin is a way to eliminate limits on innovation,creation, as an extreme manifestation of "multi-voiceness".

Traditional education is monologicaiming at transmission of knowledge represented in the textbooks assuming that there is only one correct version of reality and only one correctmethod of thinking. Dialogic education, as opposedto monologic, assumes that there is always more than one voice. More than this,dialogic education assumes that meaning is never singular but always emerges in the play ofdifferent voices in dialogue together. This dialogic approach to creativity begins with embodied, situated "living" dialogue where no-one can predict which direction the dialogue will take (Bakhtin, 1986). Open-ended dialogues are essentially creative for generating new ways of seeing a problem. The point of dialogic education, is therefore, not so much transmissionof representations, but drawing students into participation in dialogues in anultimately unbounded context (Wegerif et al., 2010; Wegerif, 2013).

For Bakhtin(1986), dialogue is assumed to be not just conversation but also shared enquiry. The English National Curriculum (Department for Education and Skills, 2006)lists thinking skills includinginformation-processing, reasoning, enquiry, creative thinking and evaluation. While some approaches to teaching thinking treat such skills as separate, other approaches treat them all as aspects of "higher order thinking". Wegerif (2006) views dialogueas the primary thinking skill upon which all others are derivative. For him, higher order thinking:

* is non-algorithmic: the path of action is not fully specified in advance so creative ideas are usually surprising;

* tends to be complex: the total path is not "visible";

* often yields multiple solutions, each with costs and benefits, rather that unique solutions;

* involves nuanced judgement and interpretation;

* involves the application of multiple criteria, which sometimes conflict with one another;

* often involves uncertainty: not everything that bears on the task at hand is ./;./;

* involvesself-regulation of the thinking process. We do not recognise higher-order thinking in an individual when someone else "calls the plays" at every step;

* involves imposing meaning, finding structure in apparent disorder; and

* iseffortful. There is considerable mental work involved in the kinds of elaborations and judgements required.

The notion of the creative dialogic space may appear, to some educationalists, as an idealised, potentiallyanarchic, view of education which holds little value for students who are motivated to pass assessmentsor achieve registration as part of a professional programme.ESD has created a necessity for such dialogic creativity or creative dialogue: A global space of interaction in which there are multiple voices. Education for creativity has a crucial role if people are to be able to thrive not onlyeconomically but also psychologically in the future.

\section{A Theoretical Framework:-}

Dialogism is based on the work of the Russian literary critic, Mikhail Bakhtin, in hisstudy of the European novel, The Dialogic Imagination (1981, trans.) and his later work on culture and language, Speech Genres (1986,trans.). Dialogism offers a significant challenge to contemporary educational practice as it opens up new pathways to valuing difference and creative pedagogical practice. He was concerned about the dangerous consequences of monologism as a result of his experiences in Stalinist Russia. His stance was that through dialogue there are creative opportunities for individuals to express their personalities (White, 2009; Stenton, 2010)).

Although Bakhtindid not applyhis insights about dialogism directly to education he presented them in formswhich educators have found very relevant. His distinction between an authoritative word anda persuasive word has obvious implications for education. The authoritative word,which he explicitly associates with school teachers, remains outside us so that we either have to accept it or reject it. He contrasts this tothe internally persuasive word that:

... is half-ours and half-someone else's. Its creativity and productiveness consistprecisely in the fact that such a word awakens new and independent words,that it organises masses of our words from within, and does not remain in anisolated and static condition(1981, p. 345). 
As a word is a "shared territory", the notion of creativity acts as a shared territoryfor meaning (Evans \& Jones, 2008).Creativity, from this perspective, developsthrough the active engagement with, and transformation of, internally persuasive discourses and is an act of learning.One would expect, then, that in a classroom, creative ideas emerge and new meanings are made through engagementwith the internallypersuasive discourses among students(Sullivan, 2011).

Supposing that creativity is a desired learning outcome, dialogism thus suggests an analytic approach for studying creativity in the classroom: a focus on theinteraction of internally persuasive discourses in students' activities. In other words, analysis should focus on howstudents make meaning based on their engagement with the classroom's material objects, the structuredenvironment, and other people in the classroom.However, schools that focus on teaching for the sake ofthe test are actually engaged in teaching students to comply with authoritative discourses.

Dialogic education is used to refer to education for dialogue and not simplyeducation through dialogue. Bakhtin distinguished dialogue from other kinds of conversation with theclaim that in dialogue there is a chain of questions and answers and each answergives rise to another question (Wegerif, 2013).The dialogic imperative is thus, "if an answer does not give rise to a new question from itself, it falls out of the dialogue" (Bakhtin, 1986; p.168). ForWhite(2009), meaning only exists in the context of a dialogue, specifically as an answer to a question.Volosinov (1986) states that"meaning is like an electric spark that occurs only when two different terminals are hooked together" p.102.This metaphor of meaningsuggests the idea ofdialogic as an opening without which there would be nomeaning.Bakhtin tends to locate this opening in the differencebetween two voices or texts in a dialogue.

That is, meaning isconstructed within dialogues. In simpler terms, it is never simplygiven but is always created out of the interaction between different voicesand different perspectives, and is reinforced by Bakhtin's point thatmeaningis always a response to a question (Bakhtin, 1986, p168). This implies that when people understand something, they do so dynamically in a communicative act that carves outone meaning from a field of competing possible meanings. The chain of meaning is said to be open, boundless and infinite (Wegerif, 2007).

The source of meaning is to be found not in the figures or in their backgrounds but in the difference between the two because it is the boundary around a figure that makes it exist as a thinkable thing. Meaning arises in dialogues where voices mutually envelop each other around an invisible gap whichis the source of creative thought. In a similar way, Bakhtin(1986) argues that understanding is a direct insight that occurs in the context of the tension between different voices in a dialogue. For him, the idea that we need to synthesise a shared single "text" out of different perspectives actually threatens the death of meaning because it threatens to close up the "infinite depth" of "contextual meaning" that opens up beneath dialogues across difference (Wegerif, 2006).

Actually, this caused a recent shift in some schools ofthought from what could be called identity thinking to what could be calleddifference thinking. The history of Westernphilosophy is dominated by the metaphor of "identity",attributed to Aristotle, that a thing is what it is and not another thing (Wegerif, 2007).Bakhtin's attention to difference and diversity through a dialogic route has the potential to embrace multiple ways of thinking about and acting in the world.

Dialogue, then, is viewed as ongoing as the basis of creative thinking. Such an approach compels the teacher to engage in dialogues characterized by paying attention to the internally persuasive discourses that exist in the classroom and their "interanimation" with authorial ones. This includes responding to students' questions, promoting rigorous debate, and engaging in learning with a sense of fun.To be creative in a Bakhtinian sense, one must take an additional step outside of the dialogue to make sense of the moment, based on what can be seen by another, a concept Bakhtin describes in his earliest works as "excess of seeing".

Wegerif(2007) describes thispositioning as one where "learner and teacher... learn to see the task through each other's eyes" p.4 - a potentially carnivalesque position (Sullivan, 2010) which can be creative so long as thestudent - most probably surprised by the notion of multi-voiced discussion including the teacher - is anequal and engaged agent in the generation of dialogue, who accepts unpredictability, respect and utilize her students' creativity. Throughout, dialogue is maintained through feedback and discussion in and outsideof the classroom and generated out of a desire to complete the task, make sense of the discursive field and receive feedback,rather than to gain marks. In this respect, then, dialogism enables students to experience learning as aprocess of changing understanding where success is driven by a willingness toadd their voice to the dialogue. 


\section{Statement of the Problem:-}

Bearing in mind the traditional lethargy in the educational system, teachers must be involved in living dialogic pace to guide students' shared learning. Participating in dialogues requires teachers to listen with respect and ask open questions.Teaching is a creative practice that requires this kind of open-minded, whole-hearted,flexible and knowledgeable orientation. Taking this view as a starting point, the present research addressed the following specific questions:

1. How canstudents be encouragedtoadapt a dialogic stance?

2. How can students be encouraged toembrace creativityas an important pedagogical process and agenda?

3. What is the participants' reaction to participating in such an experience of being creative teachers?

\section{Method:-}

\section{Design:-}

At Qassim Private Colleges, Humanities and Administration College, Buraidah, KSA, the present study was conducted during the first semester of the academic year 2015/2016. It adopted a qualitative design seeking to involve those prospective teachers in an experience learning dialogic creativity and to gather an in-depth understanding of their opinions of participating in such an experience.

\section{Subjects:-}

160 female students, enrolled in an EFL-credit programme, divided into 9 levels (one level is missing due to nonregistration), are prospective teachers of English. The instructor - the researcher -is the supervisor of the English department. They go through a preparatory year and then four academic years.

\section{Setting:-}

At the very beginning of the first term of the academic year 2015/2016, 160students were introduced to the idea of transferring the contents of their courses into creative teaching aids for using them when doing some kind of presentationof a course-related concept. The researcher asked the department instructors to supervise each level. Being divided into collaborative groups (3-8 students), each group had been assigned a task reading and interpreting text.

\section{Instruments:-}

The research data was generated by using a survey randomly asking some of those who participated in the Project Fair to talk about their experience of being creative teachers. The qualitative material wasanalysed usingthe method of narrative content analysis. The evaluation data gathered wasanalysed by the researcher.

\section{Results and Discussion:-}

The results of investigating the problem of the present study can be shown in the following way:

\section{The First Question:-}

How can students be encouraged to adapt a dialogic stance?

InWegerif's perspective (2013), participating in dialogue implies finding a voice. An individual voice onlyexists in the context of other voices. Finding one's voice within a dialogue is aboutknowing when and how to listen as well as about knowing when and how to speak.To acquire voice, students do not only need skills and knowledge, but also opportunitiesto speak as well as the motivation to do so. Teaching for voice often involves settingchallenges and knowing how much support to give and when to withdraw support.

Bearing this perspective in mind, the researcherset a competition for all students to participate in an experience of being creative teachers: divided into groups for designing teaching aids to use in presentation of the different concepts of their courses. This implied talking with them about learning how to step back,and listen with respect to the others in each group. Besides, it meant a shift from instilling the correct knowledge, skills, attitudes into the students to organizing and supporting internally persuasive discourses on the subject matters, promoting the emergence and development of the students' voices in this discourse and their informed authorship of answerable replies to others.

Isaacs (1993) describes dialogue as a sustained collective inquiry asit aims at exposing the meaningconstructions thus creating sharedunderstanding. In(1999), he mentions the principles ofdialogue: listening, respecting, voicing, 
and suspending, which is a fruitful ground for creativity.This dialogic framework helps to open and maintain a space of shared reflection within which there occurs a creative emergence of multiple ways of seeing the problem one of which is then taken up and developed as the solution.

Wals and Schwarzin (2012) endorse this view as they see a dialogue as an interactive effort toco-create novel ideas and understandings through a balanced process of inquiry,advocacy and reflection.For the present study, it was not an easy feat for a group to engage in dialogue.However, theinstructors trainedgroups to interact dialogically.Having been assigned a task, a vital element in that process of dialogic interaction was anatmosphere of mutual respect, trust and cooperation. Importantly though, it became easier to understand the phases ofconflict and instability where marginalized voices of uninterested students were encouraged while students in dominant positions engaged critically with their ownperspectives. Furthermore, the creation of a hospitable and comfortable space - alike to a cafe' environment -supportedtheir creative thinking. Participating in this experience, students were cocreators of their instructional environment in which they construct and reconstruct each other.

\section{The Second Question:-}

How can students be encouraged to embrace creativity as an important pedagogical process and agenda?

Wells(2000) explains teachers' reluctance to abandon traditional whole-class instructional methods that rely on individual seat-work and the "recitation script" due to the increasing pressure of accountability for delivering a centrally determined curriculum and for increasing students' scores on tests of memorized items of information. It is difficult for them to adopt creative practices when these practices are not supported by educational administrators and by the wider community of parents and other interested stakeholders.

Creativity may appear, at first glance, to evade the practicalities of guiding prospective teachers through a curriculum loaded with learning outcomes.However, it is a teachable skill. Subjects of the study were introduced to the notion of creativity and were asked to adopt it as an urgent agenda to survive in a turbulent age. Therefore, they were encouraged to practice it as a process through participating in an experience of being creative teachers. Thus, for answering the second question, the researcher followed four steps of creative processes mentioned by TrausanMatu(2010) as follows:

1.Preparation, immersion in interesting problematic features and arousing curiosity;

At the beginning of the first term of the academic year 2015/2016, the researcher went from a class to the other introducing the notion of creativity and announcing a competition called "The Most Creative Project". For encouraging students to participate in that competition, 10 marks specified for activities were set for that. Letting other instructors to follow up the procedure, the researcher asked them to divide students registered in each course into groups of different numbers according to their preferences.

2. Incubation, churn of ideas around the threshold of consciousness;

Each group (3-8 students) had to design a project as a teaching aid for explaining a certain concept of a course they study. They were asked to form chat groups on WhatsAppto keep in touch with each other while being at home and to set dates for gathering atcollege. Participating in dialogues, they had to be clear about the concept they were going to design a project for.

3. Insight, the "Aha!" which is the beginning to glimpse the solution;

At the same time, students had to agree upon the procedure of implementing their projects. They went through buying materials to putting everything in order till finishing their projects. Then, they had to have the acceptance of their instructors for getting the activities marks and for participating in the Project Fair.

4.Evaluation, the decision if the idea is correct and valuable.

Only valuable projects got approval for participating in the Project Fair at the end of the term. Two jurors from Home Economics and Designs College, Qassim University, were invited to participate in evaluating the projects. Those jurors designed a checklist (Appendix A) for evaluating the projects. On the Project Fair day, they and the instructors, and the researcher went through the projects to evaluate them.

The "spark" of creativity is the possibility of dialogism which is fundamentally essential to the development of professional identity of a teacher. Participating in the process of creativity, students felt its practicality and the difference it affected in their pedagogical environment; especially those students who applied it in their practicum. 
They were certain about its effectiveness in their professional development and its transferability to young students at schools.

\section{The third question:-}

What is the participants' reaction to participating in such an experience of being creative teachers?

Participation in the Project Fairwascharacterised by giving students more involvement and responsibility, for example, helping them design their learning environment either inside the college or outside it while chatting on WhatsApp or meeting for buying materials. Focusing on working creatively not only on learning, students had key responsibilities in planning a project, co-designing it, or taking on the role of a teacher and or a leader in specific ways. There was a space for the instructor's and students' voices. This allowed students to use their creativity in exploring roles and models of practice.

After the Project Fair, the researcher randomly interviewed some students to know their reaction of participating in that experience of being creative teachers. The researcher used different ways of contacting students either through the WhatsApp, e-mail or face-to-face. They answered one question:

What is your of opinion after participating is such an experience of being creative teachers?

A student explained how taking part in the study:

... articulatesmythoughts in way that I don't, because I don't have the time, I don't think of it that way. So this will now change how I think about how we run the next project.

Participation in the experiment included the development of meaningful experiences that offered andreinforced social identities and roles for students; creative learning processes such asintellectual enquiry, engagement with problems, and altered teaching and learning relationships such as those thatenabled students to lead learning.The kind of openness to action was also strongly evident which lead to a change in the educational environment all students talked about as in the following:

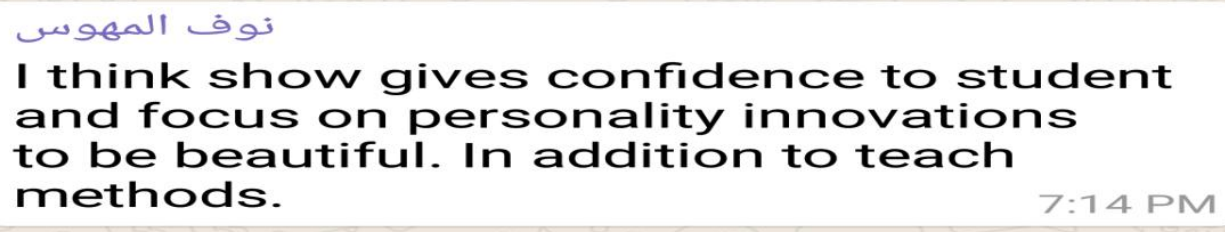

Soon after,interviews were based on a simple schedule of themes that askedparticipants to report experiences and new understandings gleaned from the experience, and included questions such as:

* How did learning and teaching happen in this context?

* What surprised you most about learning and teaching in this experience? 
* Tell me about the teaching and learning practices that most impressed you. Why?

Ylo

It was a great idea and on effective teaching is the experience and good practice.

I

Way to practice the educational tasks in

the process as it is a means of language acquisition, exercise and self-discovery capabilities and our capabilities through practice and how we deal with the teachers and school administration with appreciation and respect.

نهبي الخليفي

It's a beautiful day .. all students excelled in innovation. Have fun in training or teaching experience..

منيرة الحميدان

It was a valuable means of exchanging experiences and information related to our department, but the only thing which was not satisfying was lack of space!

While this research has some financial and organizational drawbacks, the impact on prospective teachers'growth was significant. A challenge then, within teacher education programs, is toprovide similarly immersive and extended opportunities for students to observeand absorb the potential of creative pedagogies which incorporate relevance and meaning for students, a sense of ownership and controlin the learning process.

Successful groupschanged their attitudes towards each other and towards the shared task. They became more engaged and more open, asking for help, listening to theothers, changing their minds, happy to take on each other'swords and voices and asking for advice.Those prospective teachers wouldbegin to orient towards the powerful potential of creativityin learning and teaching.

\section{Conclusion:-}

Being key change agents, teachers touch the life of everyone preparing their students to live in a different age than theirs. Therefore, they have to equip them to lead a sustainable life creatively. That is, creativity is not so much a fixed trait that an individualmight possess, but rather a process of higher order thinking and engagementthat is learnable by all. Dialogue is of the basis of this process: It is claimed to be a beforehand, pre-requisite for creativity to occur. For creativity to be a priority within schooling,prospective teachers need to understand the nature of creativity and appreciate its pedagogical value. Taking a Bakhtinian approach to dialogue, the point is not to reach necessary consensus but, through creative effort, to increase opportunities for appreciation of the others and the differences they offer to the educational landscape. 


\section{References:-}

1. Bakhtin, M. (1981).The dialogical imagination (M. Holquist, Ed., C. Emerson \& M. Holquist, Trans.). Austin, TX: University of Texas Press.

2. Bakhtin, M. (1984).Problems of Dostoevsky's poetics (C. Emerson, Ed. \& Trans.). Minneapolis: University of Michigan Press.

3. Bakhtin, M. (1986).Speech genres and other late essays (V. McGee, Trans.). Austin, TX: University of Texas Press.

4. Chappell, K. \& Craft, A. (2011).Creative learning conversations: Producing living dialogic spaces. Educational Research, 53(3): 363-385. Retrieved from https://ore.exeter.ac.uk/repository/bitstream/handle/10871/9765/Creative\%20learning\%20conversations.pdf?seq uence $=2$

5. Gore, A. (2013).The future. W.H. Allen: New York.

6. Department for Education and Skills (2006).Departmental Report.Retrieved from https://www.gov.uk/government/uploads/system/uploads/attachment_data/file/324573/DFE_Departmental_Rep ort_2006.pdf

7. Evans, J.\& Jones, P.(2008).Rethinking sustainable urban regeneration: ambiguity,creativity, and the shared territory.Environment and Planning, 40:1416-1434

8. Isaacs, W. (1993).Taking flight: Dialogue, collective thinking and organizational learning.Organizational Dynamics, 22(2): 24-39.

9. ...........(1999). Dialogue and the art of thinking together. New York: Doubleday.

10. Koschmann, T.(1999). Toward a dialogic theory of learning: Bakhtin'scontribution to understanding learning in settings ofcollaboration.Computer Support forCollaborative Learning:308-313.

11. McKeown, R. (2002). Education for sustainable development toolkit[Online]. Retrieved fromhttp://www.esdtoolkit.org

12. O'Brien, M.(2012).Fostering a creativity mindset for teaching(and learning).Learning Landscapes, 6(1): 315333.Retrieved fromhttp://www.learninglandscapes.ca/images/documents/ll-no11/mobrien.pdf

13. Smith, C. (2000). Content analysis and narrative analysis. In T.Reis andC. Judd (Eds) Handbook of research methods in social and personality psychology. (pp. 313-335). New York, NY, US: Cambridge University Press, xii, 558 pp.

14. Sullivan, F. (2011). Serious and playful inquiry: Epistemological aspects of collaborative creativity. Educational Technology \& Society, 14(1): 55-65.

15. Syvänen, S. (2014). Dialogic leadership and participatorydevelopment: Key factors of quality of working life and performance. In O. Broberg et al. (Eds) Human Factors in Organizational Design and Management - XI, Nordic Ergonomics Society Annual Conference, 46.Retrieved from http://www.dinno.fi/aineistot/ODAM\%20NES\%202014.pdf

16. ............. et al.(2012).Dialogic leadership promoting sustainable working life and innovativeness.NES2012 $\begin{array}{lllll}\text { Proceedings, } & \text { Sweden } & \text { 12-19 } & \text { August, } & \text { Retrieved }\end{array}$ http://www.nes2012.se/documents/Proceedings/Scientific/Syvanen_S.pdf

17. The Higher Education Academy (2014).Education for sustainable development and global citizenship: Evaluating and auditing ESDGC in teacher education: Belgeonne, C. et al. Retrieved from https://www.heacademy.ac.uk/sites/default/files/resources/esdgc_evaluating_and_auditing_practice.pdf

18. Tilbury, D.\&Mulà, I. (2009). Review of education for sustainable development policies from a cultural diversity and intercultural dialogue: Gaps and opportunities for future action. Paris: UNESCO.

19. Trausan-Matu, S.(2010). Computer support for creativity in small groups using chats.Annals of the Academy of Romanian Scientists Series on Science and Technology of Information, 3(2): 81-90.

20. UNESCO (2012). EFA global monitoring report 2012, youth and skills: Putting education to work, Paris: UNESCO

21. UNESCO (2013) Proposal for a global action programme on education for sustainable development as followup to the UN DESD after 2014, General Conference, 37th.Session, 4th. November 2013

22. UNESCO (2014) EFA global monitoring report 2013/4, teaching and learning: Achieving quality for all (Summary Report), Paris: UNESCO

23. UNESCO-INRULED (2012) Education and training for rural transformation: skills, jobs, food and green future to combat poverty (Beijing)

24. Voloshinov, V. (1986).Marxism and the philosophy of language.Harvard University Press.

25. Wals, A. \&Schwarzin, L. (2012).Fostering organizationalsustainability through dialogicalinteraction.The Learning Organization, 1(1): 11-27,doi: 10.1108/09696471211190338 
26. Wegerif, R. (2006). Towards a dialogic understanding of the relationship between teaching thinking and CSCL.The International Journal of Computer Supported Collaborative Learning, 1(1): 143-157, doi:10.1007/s11412-006-6840-8

27. .............. (2007). Dialogic, education and technology: Expanding the space of learning[Online]. Retrieved fromhttps://www.researchgate.net/publication/248663573

28. ............. (2013). Dialogic: Education for the Internet age.London \& New York: Routledge.

29. ..............et al. (2010). Exploring creative thinking in graphically mediated synchronous dialogues. Computers \& Education, 54: 613-621,doi: 10.1016/j.compedu.2009.10.015

30. Wells, G. (2000). Dialogic inquiry in education: building on the legacy of Vygotsky.In C. Lee and P. Smagorinsky (Eds.) Vygotskian perspectives on literacy research. New York: Cambridge University Press: 5185. Retrieved from http://people.ucsc.edu/ gwells/Files/Papers_Folder/Building\%20on\%20Vygotsky.pdf

31. White, J. (2009). Bakhtinian dialogism: A philosophical and methodological route to dialogue and difference?[Online]. $\quad$ Retrieved from http://citeseerx.ist.psu.edu/viewdoc/download?doi=10.1.1.359.7435\&rep=rep1\&type=pdf Appendix A 